\title{
Artikel
}

\section{Kinderrechten en de positie van jongvolwassenen}

\author{
E.P. (Eva) Schmidt LLM, BSc*
}

\section{Inleiding: het Internationaal Verdrag voor de Rechten van het Kind}

\subsection{Belang en successen}

Het is vrijwel onmogelijk het belang van het Internationaal Verdrag voor de Rechten van het Kind (hierna: IVRK of verdrag) op het gebied van de rechten van kinderen te overdrijven. Het aannemen van dit verdrag door de Algemene Vergadering van de Verenigde Naties (hierna: VN) in 1989 kan gezien worden als markering van het formele begin van de ontwikkeling van internationale kinderrechten als rechtsgebied, ${ }^{1}$ en werd gevolgd door een ongekend snelle, vrijwel universele ratificatie. $^{2} \mathrm{Na}$ de ratificatie hebben veel staten vervolgens op nationaal niveau uitgebreide en belangrijke veranderingen doorgevoerd om zowel wetgeving als instituten en praktijk meer in overeenstemming te

E.P. Schmidt is als promovendus werkzaam op de Afdeling Jeugdrecht, Faculteit der Rechtsgeleerdheid, Universiteit Leiden. Haar onderzoek richt zich op de bestraffing van adolescenten als kinderen of volwassenen en wordt gefinancierd door de Nederlandse Organisatie voor Wetenschappelijk Onderzoek (NWO) (projectnummer 406.18.503).

1. U. Kilkelly \& T. Liefaard, 'International Children's Rights: Reflections on a Complex, Dynamic, and Relatively Young Area of Law', in: U. Kilkelly \& T. Liefaard (red.), International Human Rights of Children, Springer 2019, p. 618.

2. S. Detrick, A Commentary on the United Nations Convention on the Rights of the Child (diss. VU Amsterdam), Den Haag: Kluwer Law International 1999, p. 1. brengen met de verplichtingen die uit het verdrag voortvloeien. ${ }^{3}$

De vraag kan gesteld worden waarom een verdrag specifiek voor kinderen noodzakelijk werd geacht. Immers, vanzelfsprekend maken alle individuen - ook kinderen aanspraak op de rechten uit de oudere, meer algemene mensenrechtenverdragen zoals het Europees Verdrag voor de Rechten van de Mens of het Internationaal Verdrag inzake Burgerrechten en Politieke Rechten. ${ }^{4}$ In de preambule van het IVRK wordt de noodzaak van een specifiek instrument als volgt, kort en bondig, toegelicht: de 'lichamelijke en geestelijke onrijpheid' van kinderen maken 'bijzondere bescherming en zorg' noodzakelijk. Daartoe zijn in het verdrag veel verschillende rechten opgenomen. Enkele bepalingen zijn meer algemeen en moeten in acht worden genomen bij het interpreteren en implementeren van het gehele verdrag. Dit zijn de zogenaamde 'general principles', waaronder bijvoorbeeld het welbekende artikel 3 lid 1, dat bepaalt dat de belangen van het kind een eerste overweging moeten vormen bij alle maatregelen die kinderen betreffen. ${ }^{5}$ Andere rechten zijn specifieker en hebben betrekking op een bepaald onderwerp, zoals - in het bijzonder relevant voor deze bijdrage - het strafrecht.

3. B. Abramson, 'Juvenile Justice: The "Unwanted Child": Why the potential of the Convention on the Rights of the Child is not being realized, and what we can do about it', in: E.L. Jensen \& J. Jepsen (red.), Juvenile Law Violators, Human Rights, and the Development of New Juvenile Justice Systems, Oxford: Hart 2006, p. 16.

4. C. Breen, Age Discrimination and Children's Rights: Ensuring Equality and Acknowledging Difference, Leiden: Martinus Nijhoff Publishers 2006, p. 12-13.

5. Zie o.a. VN-Kinderrechtencomité, General Comment No. 5 (2003): General measures of implementation of the Convention on the Rights of the Child (arts. 4, 42 and 44, para. 6), CRC/GC/2003/5, 2003, par. 12. 


\subsection{Kritiek en controverse}

Niettegenstaande het belang en de successen van het IVRK zoals hierboven beschreven, moet op dit punt worden opgemerkt dat kinderrechten veelvuldig en op verschillende vlakken worden bekritiseerd. ${ }^{6}$ Sommige critici zien deze rechten bijvoorbeeld voornamelijk als vrijheden die de autoriteit van ouders en de staat ten onrechte beperken of zelfs overtroeven. ${ }^{7}$ Daarnaast worden kinderrechten in de context van het strafrecht vaak in het bijzonder als controversieel gezien. Abramson identificeert dit gebied als het 'ongewenste kind' van de kinderrechtenbeweging. ${ }^{8}$ Staten lijken de verplichtingen uit het verdrag op dit gebied - evenals de onderliggende redenen voor een afzonderlijk jeugdstrafrechtsysteem - niet volledig te begrijpen, accepteren en/of implementeren. ${ }^{9}$

Er zijn verschillende redenen aan te wijzen voor het feit dat de erkenning en implementatie van kinderrechten op het gebied van het strafrecht omstreden zijn. Maatschappelijk gezien bestaat over het algemeen grote interesse in en discussie rondom jeugdcriminaliteit - vaak gevoed door (niet altijd even genuanceerde) politieke retoriek en berichtgeving in de media, en veelal op basis van hardnekkige misvattingen. ${ }^{10}$ De grote belangstelling vanuit de samenleving is onder meer te verklaren doordat de maatschappelijke belangen op dit vlak - zoals bescherming tegen en preventie van criminaliteit, alsmede vergelding en genoegdoening voor eventuele slachtoffers en nabestaanden - op het eerste gezicht niet per se overeen lijken te komen met de belangen van de jeugdige dader. ${ }^{11}$

Ook het beeld van de jeugdige dader speelt een belangrijke rol in de controverse rondom kinderrechten op het gebied van het strafrecht. Minderjarigen die strafbare feiten plegen behoren tot de meest gemarginaliseerde groepen kinderen in de samenleving. ${ }^{12}$ Daarnaast wordt in het IVRK consequent gesproken van het 'kind'. Het idee van een dader strookt echter niet met het dominante beeld van kinderen als hulpeloze en onschuldige

6. Zie hierover bijvoorbeeld P. Alderson, 'Common Criticisms of Children's Rights and 25 Years of the IJCR', International Journal of Children's Rights 2017, afl. 2, p. 307-319.

7. Zie voor deze en andere kritieken, alsmede verschillende tegenargumten, M. Freeman, 'Why It Remains Important to Take Children's Rights Seriously', International Journal of Children's Rights 2007, afl. 1, p. 5-23 en C. Huntington \& E.S. Scott, 'Conceptualising Legal Childhood in the Twenty-First Century', Columbia Public Law Research Paper no. 14-663, 2019, p. 1-70.

8. Abramson 2006, p. 15.

9. Abramson 2006, p. 21-22.

10. Abramson 2006, p. 22; T. Liefaard, 'Juvenile justice from an international children's rights perspective', in: W. Vandenhole e.a. (red.), Routledge Handbook of Children's Rights Studies, London/New York: Routledge, Taylor \& Francis Group 2015, p. 235.

11. Liefaard 2015, p. 235 . Zowel vanwege de leesbaarheid als vanwege het feit dat dit de meest gebruikte term is in de (internationale) literatuur en internationale juridische instrumenten met betrekking tot dit onderwerp, zal in deze bijdrage over het algemeen van 'daders' gesproken worden. Waar 'dader' wordt genoemd, kan echter 'verdachte of dader' worden ingelezen.

12. Liefaard 2015, p. 235 wezens. ${ }^{13}$ Zeker in het geval van ernstige feiten is wel opgemerkt dat met betrekking tot de jeugdige dader een zogenaamde 'conceptual eviction' plaatsvindt. Daarmee wordt bedoeld dat in dergelijke gevallen - waarin het kind dus niet voldoet aan het beeld van een 'normale', onschuldige jeugdige - de heersende opvatting is dat de jeugdige in het geheel niet meer in de categorie 'kind' zou moeten vallen. ${ }^{14}$

Hoewel ieder individu beneden de leeftijd van 18 jaar in beginsel aanspraak maakt op de rechten uit het IVRK, lijkt de veronderstelling bij kinderrechten niet automatisch te zijn dat deze ook zouden moeten gelden voor 'oudere kinderen', oftewel adolescenten. ${ }^{15}$ Het is moeilijk om adolescentie, de periode tussen kindertijd en volwassenheid, precies te definiëren aan de hand van leeftijden. ${ }^{16}$ De aandacht voor deze periode is de afgelopen decennia echter op internationaal niveau toegenomen en heeft, zoals uit het vervolg van deze bijdrage zal blijken, mogelijk consequenties voor de interpretatie en implementatie van kinderrechten op het gebied van het strafrecht. In toenemende mate wordt namelijk de vraag gesteld tot welke leeftijd individuen zich blijven ontwikkelen en of niet alleen minderjarige adolescenten, maar ook jongvolwassenen aanspraak zouden moeten kunnen maken op deze rechten.

\section{Aanleiding en probleemstelling}

Bij het lezen van artikel 1 van het IVRK lijkt het in beginsel duidelijk wie aanspraak maakt op de rechten die daarin zijn vastgelegd: 'Voor de toepassing van dit Verdrag wordt onder een kind verstaan ieder mens jonger dan achttien jaar, tenzij volgens het op het kind van toepassing zijnde recht de meerderjarigheid eerder wordt bereikt'. ${ }^{17}$ De onderbouwing en het nut van deze leeftijdsgrens kunnen echter op verschillende rechtsgebieden ter discussie worden gesteld. Zo noemt De Jong het in haar proefschrift over 'transitiejongeren' - jongmeerderjarigen in de leeftijd van 18 tot ongeveer 25 jaar die de residentiële jeugdhulpverlening verlaten - problematisch, dat de leeftijdsgrens van 18 jaar niet is vastgesteld

13. Abramson 2006, p. 24.

14. N. Lynch, "Human Rights for "Hard Cases": Alternatives to Imprisonment for Serious Offending by Children and Youth', in: E. Stanley (red.), Human Rights and Incarceration: Critical Exploration, Springer 2018, p. 216

15. Abramson 2006, p. 25.

16. UNICEF 2011, The State of the World's Children 2011. Adolescence: An Age of Opportunity, UNICEF 2011 (beschikbaar via unicef.org), p. 8-12; VN-Kinderrechtencomité, General comment No. 20 (2016) on the implementation of the rights of the child during adolescence, CRC/C/GC/20, 2016, par. 5

17. Hierbij moet opgemerkt worden dat het VN-Kinderrechtencomité staten aanspoort om inderdaad de leeftijd van 18 jaar en geen lagere leeftijd als grens te hanteren. Zie D. Archard \& J. Tobin, 'Article 1: The Definition of a Child', in: J. Tobin (red.), The UN Convention on the Rights of the Child: A Commentary, Oxford: Oxford University Press 2019, p. 27-29. 
'op basis van een fundamentele theorievorming over de ontwikkeling van kinderen', en dat een inhoudelijke onderbouwing hiervan lijkt te ontbreken. ${ }^{18}$ De Jong stelt deze leeftijdsgrens vervolgens ter discussie op grond van 'sociaalwetenschappelijke en medisch-wetenschappelijke inzichten' en vraagt zich af of de jongmeerderjarigen waarnaar zij onderzoek doet, niet ook onder de bescherming van het verdrag zouden moeten vallen. ${ }^{19}$

Inderdaad hebben zich, sinds het aannemen van het IVRK dertig jaar geleden, interessante ontwikkelingen voorgedaan met betrekking tot de kennis over de ontwikkeling van adolescenten en de aandacht voor de positie van jongvolwassenen. ${ }^{20}$ Deze ontwikkelingen maken het relevant om te bestuderen in hoeverre de leeftijdsgrens van 18 jaar nog doorslaggevend zou moeten zijn voor het bepalen van het bereik van de rechten die in het verdrag zijn opgenomen.

Dit alles roept de vraag op of jongvolwassenen wellicht ook aanspraak (zouden moeten) kunnen maken op deze rechten. Het antwoord op deze vraag wordt in deze bijdrage verkend, met speciale aandacht voor de relevantie van deze rechten voor jongvolwassenen in de context van het strafrecht. Daartoe wordt eerst, in paragraaf 3.1, ingegaan op de oorsprong en onderbouwing, en in paragraaf 3.2 op de inhoud van kinderrechten voor minderjarigen in de context van het strafrecht. Hiervoor wordt gekeken naar de relevante verdragsbepalingen uit het IVRK en de toelichting daarbij door het comité. Vervolgens wordt in paragraaf 4.1 meer specifiek gekeken naar de oorsprong en onderbouwing van het idee van kinderrechten voor adolescenten en jongvolwassenen. Opnieuw wordt daarbij gekeken naar het IVRK en de - vrij recente - ontwikkelingen in het werk van het comité op dit gebied. Zoals zal blijken, verwijst het comité slechts kort naar 'de' relevante wetenschappelijke inzichten. In paragraaf 4.2 wordt daarom uitgebreider bij deze ontwikkelingen stilgestaan, evenals bij de potentiële implicaties daarvan voor de positie van jongvolwassenen in het strafrecht. In paragraaf 5 wordt ingegaan op de positie van adolescenten en jongvolwassenen in het Nederlandse straf(proces)recht, waarmee het belang van het kinderrechtenkader voor deze groepen nader wordt geillustreerd. In paragraaf 6 wordt afgesloten met enkele concluderende opmerkingen.

Op deze plaats moet voor de duidelijkheid worden opgemerkt dat in deze bijdrage met 'kinderen' verwezen

18. R. de Jong, Zorg(e)loze jeugd. Een multidisciplinair onderzoek naar de juridische grondslag voor de gedwongen bescherming van transitiejongeren (diss. Tilburg University), Apeldoorn/Antwerpen: Maklu 2019 p. 170.

19. De Jong 2019 , p. 170

20. Zie met betrekking tot adolescenten bijv. M.D. Ruck e.a., 'The United Nations Convention on the Rights of the Child: Its Relevance for Adolescents', Journal of Research on Adolescence 2014, afl. 1, p. 16-29 en met betrekking tot jongvolwassenen S. Matthews, V. Schiraldi \& L. Chester, 'Youth Justice in Europe: Experience of Germany, the Netherlands, and Croatia in Providing Developmentally Appropriate Responses to Emerging Adults in the Criminal Justice System', Justice Evaluation Journal 2018, afl. 1, p. 59-81. wordt naar individuen jonger dan 18 jaar, met 'adolescenten' naar individuen vanaf ongeveer 15 tot 18 jaar, en met 'jongvolwassenen' naar individuen van 18 tot ongeveer 25 jaar. Hoewel op basis van wetenschappelijke inzichten beargumenteerd kan worden dat adolescentie doorloopt tot na het achttiende jaar, zal in deze bijdrage - gezien de in juridisch opzicht nog immer dominante leeftijdsgrens van 18 jaar - dus worden gesproken van ‘adolescenten en jongvolwassenen'.

\section{Kinderrechten en het strafrecht}

\subsection{Oorsprong en onderbouwing}

Zoals in de inleiding werd benoemd, is het IVRK gebaseerd op het idee dat de lichamelijke en geestelijke onrijpheid van kinderen specifieke bescherming van deze groep noodzakelijk maken. Dit is later herhaaldelijk en nog wat explicieter benadrukt door het comité in de context van het strafrecht: voor het eerst in het oorspronkelijke General Comment op dit gebied (General Comment No. 10) en zeer recent nogmaals in de vernieuwde versie daarvan. ${ }^{21}$ In het laatstgenoemde document, General Comment No. 24, overweegt het comité: 'Kinderen verschillen van volwassenen in hun fysieke en psychische ontwikkeling. Dergelijke verschillen vormen de basis voor de erkenning van een lagere verwijtbaarheid en voor een afzonderlijk systeem met een gedifferentieerde, geïndividualiseerde aanpak. Blootstelling aan het strafrechtelijk systeem blijkt schadelijk te zijn voor kinderen en beperkt hun kansen om verantwoordelijke volwassenen te worden. ${ }^{22}$

\subsection{De rechten nader beschouwd}

De specifieke rechten voor kinderen in de context van het strafrecht worden dus zowel onderbouwd door een terugblik op het gepleegde strafbare feit waarbij sprake was van verminderde verwijtbaarheid, als door een blik vooruit op de toekomst waarin het kind zo goed mogelijk de volwassenheid zou moeten kunnen bereiken. Op deze fundering wordt in het IVRK en in verschillende General Comments nader bepaald op welke rechten kinderen daartoe aanspraak zouden moeten kunnen maken. Op het gebied van het strafrecht zijn, wat betreft de meer specifieke rechten, zowel artikel 37 als met name ook artikel 40 van het IVRK in het bijzonder van belang. ${ }^{23}$ Artikel 37 heeft betrekking op het verbod op foltering en op een andere wrede, onmenselijke of onterende behandeling of bestraffing en bevat daarnaast

21. Zie resp. VN-Kinderrechtencomité, General Comment No. 10 (2007): Children's Rights in juvenile justice, CRC/C/GC/10, 2007, par. 10 en VN-Kinderrechtencomité, General Comment No. 24 (2019) on children's rights in the child justice system, CRC/C/GC/24, 2019, par. 2.

22. Overgenomen uit de Nederlandse vertaling door het Ministerie van VWS van General Comment No. 24 (2019) on children's rights in the child justice system (beschikbaar via kinderrechten.nl/generalcomments-nederlandse-vertaling/), par. 2.

23. Liefaard 2015, p. 237-254. 
verschillende waarborgen met betrekking tot de vrijheidsbeneming van kinderen. Artikel 40 stelt daarnaast meer in het algemeen verschillende eisen aan het jeugdstrafrechtsysteem van verdragsstaten.

Daarnaast heeft het comité meer in het algemeen benadrukt dat een strikt punitieve benadering niet in overeenstemming is met artikel 40 lid 1 IVRK. ${ }^{24}$ Ook in het General Comment die is gewijd aan het recht van het kind om zijn of haar belangen de eerste overweging te laten zijn (General Comment No. 14) is door het comité aangegeven dat 'bescherming van de belangen van het kind betekent dat bij jeugdige daders de traditionele doestellingen van het strafrecht, zoals repressie of vergelding, plaats moeten maken voor doelstellingen in het kader van rehabilitatie en herstelrecht'. ${ }^{25}$ Trépanier heeft opgemerkt dat bij beslissingen die met betrekking tot jeugdigen in het strafrecht worden genomen, op grond van het internationale recht constant sprake is van het tegen elkaar afwegen van de behoeften van de jeugdige, de ernst van het feit en de behoeften van de samenleving. ${ }^{26}$ Het comité heeft over deze balans opgemerkt, dat aan het doel van het behouden van openbare veiligheid invulling moet worden gegeven met inachtneming van de verplichtingen uit het IVRK. ${ }^{27}$ Verder wordt door het comité met name nadruk gelegd op de behoeften van de samenleving op de lange termijn, ${ }^{28}$ hetgeen voornamelijk lijkt te verwijzen naar het voorkomen van verdere criminaliteit. Volgens die benadering komen het belang van de samenleving (veiligheid) en het belang van het kind (re-integratie) overeen.

Zoals reeds eerder werd benoemd, bepaalt artikel 1 van het IVRK in beginsel het bereik van de in het verdrag vastgelegde rechten: deze gelden voor individuen van 18 jaar of jonger. In de context van het strafrecht heeft het comité bovendien benadrukt dat hierbij de leeftijd ten tijde van het begaan van het strafbare feit bepalend is. ${ }^{29}$ Ook heeft het comité expliciet aandacht besteed aan de positie van kinderen die de leeftijdsgrens van 18 jaar passeren gedurende het doorlopen van een strafrechtelijke procedure of interventie: hun positie in het jeugstrafrecht zou in beginsel behouden moeten worden. ${ }^{30}$ In de volgende paragraaf wordt nader bekeken of jongvolwassenen daarnaast eveneens in meer algemene zin aanspraak (zouden moeten) kunnen maken op de rechten uit het IVRK.

24. VN-Kinderrechtencomité 2019, par. 76

25. Overgenomen uit de Nederlandse vertaling door het Ministerie van VWS van General Comment No. 14 (2013) on the right of the child to have his or her best interests taken as a primary consideration (art. 3, para. 1) (beschikbaar via kinderrechten.nl/general-commentsnederlandse-vertaling/), par. 28

26. J. Trépanier, 'The Roots and Development of Juvenile Justice: An International Overview', in: J. Trépanier \& X. Rousseaux (red.), Youth and Justice in Western States, 1815-1950. From Punishment to Welfare, Cham: Palgrave Macmillan 2018, p. 48.

27. VN-Kinderrechtencomité 2019, par. 3.

28. Zie bijv. in VN-Kinderrechtencomité 2019, par. 76.

29. VN-Kinderrechtencomité 2019, par. 29-31.

30. VN-Kinderrechtencomité 2019, par. 31, 35

\section{Kinderrechten voor jongvolwassenen?}

\subsection{Oorsprong en onderbouwing}

Zoals hierboven werd beschreven, zijn kinderrechten in het algemeen en in de context van het strafrecht in het bijzonder geënt op het idee van een verschil in ontwikkeling tussen volwassenen en kinderen. De ontwikkeling van kinderen is nog niet voltooid, hetgeen hun handelen minder verwijtbaar maakt en hetgeen ook oproept tot bezinning op de gevolgen van (strafrechtelijke) interventies voor hun ontwikkeling naar volwassenheid.

De aandacht voor de ontwikkeling van kinderen tot volwassenen binnen dit rechtsgebied is niet vreemd. In de literatuur wordt er wel op gewezen dat al langer sprake is van verbindingen tussen internationaal recht en andere disciplines zoals psychologie, psychiatrie en neurowetenschappen; zo zou ontwikkelingspsychologie invloed hebben gehad op het hedendaagse beeld van het kind en op de tekst van het IVRK zelf, waarin de term 'ontwikkeling' herhaaldelijk voorkomt. ${ }^{31}$ Zoals reeds werd genoemd, is het verdrag inmiddels dertig jaar geleden aangenomen en reflecteert het duidelijk de kennis en opvattingen van die tijd. ${ }^{32}$ Tegelijkertijd bevorderen het verdrag en de aanpalende kinderrechtenbeweging juist ook de aandacht en het begrip voor de ontwikkeling van kinderen en adolescenten. Zo is het comité redelijk recent verschillende keren nader ingegaan op het belang van aandacht voor ontwikkeling in de context van het strafrecht.

\subsubsection{Adolescenten}

Allereerst nam het comité in 2016 een General Comment aan die volledig was gewijd aan kinderrechten gedurende de adolescentie, General Comment No. 20. ${ }^{33}$ Hierin verwijst het comité naar adolescentie als 'een uniek, bepalend stadium van menselijke ontwikkeling, gekenmerkt door snelle hersenontwikkeling en fysieke groei, sterker cognitief vermogen, het begin van puberteit en seksueel bewustzijn en nieuwe vermogens, sterke punten en vaardigheden die zich aandienen.' ${ }^{34}$ Het comité ziet adolescentie als een belangrijke periode van transitie, die zowel kansen als risico's met zich meebrengt, en die een belangrijke impact heeft op de daaropvolgende levensfasen. ${ }^{35}$ In General Comment No. 20 wordt aandacht besteed aan verschillende onderwerpen

31. N. Peleg \& J. Tobin, 'Article 6: The Rights to Life, Survival and Development', in: J. Tobin (red.), The UN Convention on the Rights of the Child: A Commentary, Oxford: Oxford University Press 2019, p. 224-225.

32. De Jong 2019 , p. 170

33. VN-Kinderrechtencomité 2016. Zie hieromtrent ook E.P. Schmidt, 'De implementatie van kinderrechten tijdens de adolescentie: General Comment No. 20 en de positie van adolescenten in het Nederlandse strafrecht', TVJr 2019, afl. 2, p. 55-61.

34. Overgenomen uit de Nederlandse vertaling door het Ministerie van VWS van General comment No. 20 (2016) on the implementation of the rights of the child during adolescence (beschikbaar via kinderrechten.nl/general-comments-nederlandse-vertaling/), par. 9.

35. VN-Kinderrechtencomité 2016, par. 8-13. 
die in het bijzonder van belang zijn gedurende de adolescentie. Een daarvan is de positie van adolescenten in het strafrechtsysteem. Het comité stelt onder meer dat maatregelen nodig zijn om de kwetsbaarheid van adolescenten in het strafrecht, zowel in de hoedanigheid van slachtoffers als in de hoedanigheid van daders, te verminderen en geeft aan dat de nadruk ook voor deze groep moet liggen op rehabilitatie en re-integratie. ${ }^{36}$

Overigens focust het comité in dit General Comment op de periode van 10 tot 18 jaar, hoewel het hierbij expliciet stelt dat hiermee niet wordt beoogd een definitie te geven. ${ }^{37}$ De Jong benadrukt dat deze interpretatie van adolescentie door het comité beduidend beperkter is dan de interpretatie die eraan gegeven wordt in de sociale en medisch-wetenschappelijke literatuur, hoewel het comité ook vaststelt dat deze periode niet per se een duidelijk begin of einde kent. ${ }^{38}$

\subsubsection{Jongvolmassenen}

Verder heeft het comité in verschillende documenten ook (kort) specifiek aandacht besteed aan jongvolwassenen. Reeds in het oorspronkelijke General Comment over kinderrechten in de context van het strafrecht stond het comité positief tegenover verdragsstaten die het jeugdstrafrechtsysteem in het algemeen of bij wijze van uitzondering toepassen op individuen van 18 jaar en ouder - meestal, aldus het comité, tot de leeftijd van 21 jaar. ${ }^{39}$ Een vergelijkbaar positief standpunt is te vinden in General Comment No. 24, waarbij opvalt dat het comité dit keer niet meer verwijst naar een bovengrens van 21 jaar en bovendien toevoegt: 'Deze aanpak is in overeenstemming met het ontwikkelings- en neurowetenschappelijk bewijs dat aantoont dat de hersenontwikkeling doorgaat tot in de vroege jaren twintig. ${ }^{40}$ In de introductie van General Comment No. 24 stelde het comité al dat dit nieuwe document op het gebied van kinderen en het strafrecht de ontwikkelingen sinds 2007 weerspiegelt, onder meer met betrekking tot kennis over de ontwikkeling van kinderen en adolescenten. ${ }^{41}$

Deze verwijzing naar ontwikkelings- en neurowetenschappen is in beginsel positief - denk hierbij ook aan de eerder aangehaalde kritiek over het gebrek aan inhoudelijke onderbouwing van de leeftijdsgrens van 18 jaar uit artikel 1 IVRK. ${ }^{42}$ Er valt echter beduidend meer te zeggen dan het comité heeft gedaan, over de hedendaagse inzichten in de ontwikkeling van adolescenten, zowel beneden als boven de leeftijd van 18 jaar, en de mogelijke implicaties daarvan voor de positie van jongvolwassenen in het strafrecht. Daartoe wordt in de volgende paragraaf een aanzet gedaan.

36. VN-Kinderrechtencomité 2016, par. 87-88.

37. VN-Kinderrechtencomité 2016, par. 5.

38. De Jong 2019, p. 171-172.

39. VN-Kinderrechtencomité 2007, par. 38.

40. Overgenomen uit de Nederlandse vertaling door het Ministerie van VWS van General Comment No. 24 (2019) on children's rights in the child justice system (beschikbaar via kinderrechten.nl/generalcomments-nederlandse-vertaling/), par. 32.

41. VN-Kinderrechtencomité 2019, par. 1.

42. De Jong 2019, p. 170
4.2. Inzichten in de ontwikkeling van

adolescenten en jongvolwassenen

De afgelopen decennia is het besef gegroeid dat de ontwikkeling van adolescenten op veel vlakken doorgaat na de leeftijd van 18 jaar, hoewel het onderzoek dat dit bewustzijn heeft gevoed op sommige vlakken nog volop in ontwikkeling is. ${ }^{43}$ Desalniettemin lijken inzichten uit de ontwikkelingspsychologie en neurowetenschappen er, in ieder geval voorzichtig, op te wijzen dat jongvolwassenen in bepaalde, voor het strafrecht relevante opzichten op (minderjarige) adolescenten lijken. Onderzoek naar de psychologische en neurologische ontwikkeling van adolescenten heeft aangetoond dat deze doorgaat tot na het twintigste levensjaar, hetgeen implicaties heeft voor psychologische functies als planning, flexibiliteit, emotieregulatie, het afremmen van impulsen en het kijken naar langetermijngevolgen en risico's. ${ }^{44}$ Ook is de invloed van leeftijdsgenoten gedurende de adolescentie groot. ${ }^{45}$ Dit alles heeft uiteraard belangrijke consequenties voor de manier waarop adolescenten en jongvolwassenen beslissingen maken en voor het (risico)gedrag dat zij vertonen.

Daarnaast kunnen in dit kader ook enkele andere relevante inzichten worden aangehaald. Zo blijkt uit sociologisch onderzoek, dat de transitie van jeugd naar volwassenheid tegenwoordig langer duurt dan vroeger en dat bepaalde mijlpalen, bijvoorbeeld op het vlak van relaties, opleiding en werk, inmiddels later worden bereikt. ${ }^{46}$ Deze mijlpalen wijzen er niet alleen op dat een individu daadwerkelijk onafhankelijk (en dus: volwassen) is geworden, maar zijn bovendien beschermende factoren als het gaat om criminaliteit. ${ }^{47}$ Het is ontegenzeggelijk moeilijk om de invloed van deze inzichten op criminaliteit te ontrafelen. Toch lijken zelfs de meer terughoudende wetenschappers van oordeel dat de gedragspatronen tijdens jongvolwassenheid erop duiden dat de ontwikkelingsfactoren die bijdragen aan jeugdcriminaliteit ook jongvolwassenen beïnvloeden. ${ }^{48}$

Wat betreft de relatie tussen crimineel gedrag en leeftijd moet hier worden opgemerkt dat de 'age-crime curve' in westerse samenlevingen een van de meest bekende en consistente bevindingen is uit de criminologie. ${ }^{49} \mathrm{Dit}$ fenomeen houdt in dat criminaliteitscijfers stijgen tij-

43. Zie bijvoorbeeld voor een volledige maar voorzichtige discussie E.S. Scott, R.J. Bonnie \& L. Steinberg, 'Young Adulthood as a Transitional Legal Category: Science, Social Change, and Justice Policy', Fordham Law Review 2016, afl. 2, p. 641-666.

44. T. Doreleijers \& J.W. Fokkens, 'Minderjarigen en jongvolwassenen: pleidooi voor een evidence based strafrecht', Rechtstreeks 2010, afl. 2, p. 24; Matthews, Schiraldi \& Chester 2018, p. 2; E.P. Schmidt, S.E. Rap \& T. Liefaard, 'Young Adults in the Justice System: The Interplay between Scientific Insights, Legal Reform and Implementation in Practice in The Netherlands', Youth Justice 2020, p. 3-5, DOI:10.1177/ 1473225419897316; Scott, Bonnie \& Steinberg 2016, p. 648-652.

45. Schmidt, Rap \& Liefaard 2020, p. 4-5.

46. Doreleijers \& Fokkens 2010, p. 25; Matthews, Schiraldi \& Chester 2018, p. 2.

47. Matthews, Schiraldi \& Chester 2018, p. 2 .

48. Scott, Bonnie \& Steinberg 2016, p. 646-648.

49. Zie T. Hirschi \& M. Gottfredson, 'Age and the Explanation of Crime', American Journal of Sociology 1983, afl. 3, p. 552-584 en recenter 
dens de late adolescentie en vroege volwassenheid als gevolg van een toename in het aantal daders, voordat deze later in de volwassenheid weer afnemen. Scott, Bonnie en Steinberg stellen op basis hiervan het volgende over jongvolwassenheid als unieke periode in de ontwikkeling: 'Research on the developmental trajectory of criminal behavior has consistently documented an agelinked pattern of offending - the "age-crime curve" - in which rates of criminal behavior increase over the course of adolescence, peak around age eighteen, and then decline during the early twenties. Therefore, young adulthood is both the stage during which criminal behavior is most common and the period during which the vast majority of offenders begin desisting from crime. In this regard, young adulthood is arguably the most significant transitional period in the development of criminal behavior. ${ }^{50}$ Het benaderen van daders uit deze groep op basis van hun ontwikkeling en behoeften zou effectiever zijn ter voorkoming van verder crimineel gedrag - en daarmee ook meer in het maatschappelijk belang van veiligheid - dan een automatische overheveling van daders naar het reguliere, 'volwassen' strafrecht direct na hun achttiende verjaardag. ${ }^{51}$

Gebaseerd op het bovenstaande kan dus gesteld worden dat de redenen om minderjarigen kinderrechten toe te kennen in de context van het strafrecht - een verschil in ontwikkeling met volwassenen, dat gevolgen heeft voor de mate van verwijtbaarheid en de mogelijkheid een positieve ontwikkeling naar volwassenheid door te maken - ook van toepassing lijken te zijn op jongvolwassenen.

\section{Adolescenten en jongvolwassenen in het Nederlandse straf(proces)recht}

\subsection{Recente ontwikkelingen}

Het potentiële belang van het IVRK en het werk van het Kinderrechtencomité voor adolescenten en jongvolwassenen in het strafrecht kan worden geillustreerd door de ervaringen in het Nederlandse strafrechtsysteem. Ook hier is de afgelopen jaren aandacht besteed aan de positie van adolescenten en jongvolwassenen. Onder verwijzing naar de oververtegenwoordiging van deze groep in de criminaliteitsstatistieken, alsmede recente wetenschappelijke inzichten inzake hun (onvoltooide) ontwikkeling, werd in 2014 de Wet adolescentenstrafrecht ingevoerd. ${ }^{52}$ Hierdoor werd de mogelijkheid uitgebreid

bijvoorbeeld J.M. Hill, On the road to adulthood. Delinquency and desistance in Dutch emerging adults (diss. Universiteit Leiden), 2017.

50. Scott, Bonnie \& Steinberg 2016, p. 645

51. Zie ook Matthews, Schiraldi \& Chester 2018; Scott, Bonnie \& Steinberg 2016.

52. Kamerstukken II 2012/13, 33498, 3, p. 1-2, 12-13 (MvT); Stb. 2013 485; Stb. 2014, 33; M.A.H. Kempen, 'Het adolescentenstrafrecht: een om jongvolwassenen onder het jeugdstrafrecht te bestraffen: voorheen was dit mogelijk voor jongvolwassenen tot 21 jaar; sinds 2014 is dit mogelijk voor jongvolwassenen tot 23 jaar ten tijde van het begaan van het strafbare feit. Deze mogelijkheid is opgenomen in artikel 77c Wetboek van Strafrecht (Sr), dat bepaalt dat de rechter het materiële jeugdstrafrecht kan toepassen op een jongvolwassene, indien hij of zij daartoe grond vindt in de persoonlijkheid van de dader of de omstandigheden waaronder het feit is begaan. Overigens is in het kader van de modernisering van het Wetboek van Strafvordering $(\mathrm{Sv})$ in het voorgestelde nieuwe Boek 6 een bepaling opgenomen, die het voor de rechter mogelijk moet maken om tijdens elke fase van het strafproces toepassing te geven aan het jeugdstrafprocesrecht, indien hij of zij daartoe aanleiding ziet in de persoonlijkheid van de jongvolwassene, of de omstandigheden waaronder het feit is begaan. ${ }^{53}$ De hoofdregel blijft overigens tot op heden dat op degene die ouder was dan 12 jaar maar jonger dan 18 jaar ten tijde van het strafbare feit, de materiële en procedurele bepalingen van het jeugdstrafrecht worden toegepast. ${ }^{54}$

\subsection{De positie van jongvolwassenen}

Welke jongvolwassenen precies voor bestraffing binnen het jeugdstrafrecht in aanmerking komen en waarom, is noch in de wetgeving, noch in de juridische praktijk voldoende duidelijk geworden. ${ }^{55}$ Zo werd de ernst van het begane feit voorafgaand aan de invoering door de verantwoordelijke Staatssecretaris van (destijds nog) Veiligheid en Justitie als indicatie genoemd om te onderzoeken of het jeugdstrafrecht kan worden toegepast, maar later juist - in combinatie met de aanwezigheid van eventuele slachtoffers dan wel nabestaanden als contra-indicatie voor de uiteindelijke toepassing daarvan. ${ }^{56}$

Ook de andere, in artikel 77c Sr opgenomen redenen om het jeugdstrafrecht op jongvolwassenen toe te passen, zijn niet eenduidig toegelicht. Met betrekking tot 'de persoonlijkheid van de dader' worden in de memorie van toelichting bijvoorbeeld specifieke groepen genoemd die in aanmerking zouden kunnen komen voor de toepassing van het jeugdstrafrecht, waaronder jongvolwassenen met een ontwikkelings-, psychische of psychiatrische stoornis. ${ }^{57}$ Hoe deze specifieke groepen zich verhouden tot het eveneens genoemde concept van 'onvoltooide ontwikkeling' dat in dit kader van belang zou zijn, wordt niet uitgelegd. ${ }^{58}$ Ook veelplegers worden

flexibel sanctiestelsel voor jongvolwassenen', Tijdschrift voor Familieen Jeugdrecht 2014, afl. 5 .

53. Art. 6.1.1.4.2 van het wetsvoorstel tot vaststelling van Boek 6 van het nieuwe Wetboek van Strafvordering: Bijzondere regelingen, via Rijksoverheid.nl.

54. Art. $77 \mathrm{a}$ Sr en art. 486 en 488 lid 2 Sv.

55. Zie hierover onder meer Schmidt, Rap \& Liefaard 2020

56. Zie resp. Kamerstukken // 2012/13, 33498, 3, p. 6, 21-22 en Handelingen // 2012/13, 89, item 4, p. 5.

57. Kamerstukken // 2012/13, 33498, 3, p. 21-22.

58. L.J.C. Prop e.a., Adolescentenstrafrecht. Kenmerken van de doelgroep, de strafzaken en de tenuitvoerlegging, Den Haag: WODC 2018, p. 30-31. 
in de memorie van toelichting genoemd als mogelijke doelgroep voor de toepassing van het jeugdstrafrecht. ${ }^{59}$ In de instrumenten die door de reclassering en het Nederlands Instituut voor Forensische Psychiatrie en Psychologie (NIFP) gebruikt worden voor het adviseren over een jongvolwassene, geldt justitiële voorgeschiedenis echter als contra-indicatie voor het toepassen van het jeugdstrafrecht. ${ }^{60} \mathrm{Al}$ eerder werd op basis van interviews met officieren van justitie geconcludeerd dat kennis aangaande de ontwikkeling van adolescenten en jongvolwassenen geen motivatie of indicatie leek om een beroep te doen op toepassing van artikel $77 \mathrm{c} \mathrm{Sr}$, en dat de ernst van het feit over het algemeen als contra-indicatie wordt geinterpreteerd. ${ }^{61}$ Uit recenter onderzoek door het WODC blijkt, dat voor zowel officieren van justitie als rechters geldt dat de ernst van het feit voor sommige professionals een reden is om geen sanctie uit het jeugdstrafrecht te vorderen of op te leggen, maar voor andere niet. ${ }^{62}$ Onderzoek na invoering van de Wet adolescentenstrafrecht toonde verder aan dat de toepassing van artikel 77c Sr beperkt bleef tot ongeveer 5\% van alle strafzaken tegen jongvolwassenen. ${ }^{63}$

\subsection{Het belang van het kinderrechtenkader nader geillustreerd}

Het IVRK en het werk van het Kinderrechtencomité zouden een relevant startpunt kunnen bieden voor nadere reflectie op de positie van jongvolwassenen in het Nederlandse strafrecht, die tot op heden helaas dus nog onduidelijk en onderbelicht blijft. Eerder in deze bijdrage werd reeds benoemd dat de rechtvaardiging van een aparte positie voor jeugdigen in het strafrecht door het Kinderrechtencomité wordt gevonden in het verschil in ontwikkeling tussen kinderen en volwassenen, hetgeen consequenties heeft voor de verwijtbaarheid van kinderen en voor de mogelijkheden die hen geboden zouden moeten worden om zo goed mogelijk de volwassenheid te bereiken. ${ }^{64}$ Deze rechtvaardiging is voor een groot deel ook toepasbaar op jongvolwassenen: wat betreft de verminderde verwijtbaarheid is het relevant dat inmiddels wordt aangenomen dat ontwikkelingsfactoren die bijdragen aan jeugdcriminaliteit ook van invloed zijn gedurende de jongvolwassenheid, en met betrekking tot de positieve ontwikkeling naar volwassenheid moet opgemerkt worden dat jongvolwassenheid een unieke periode in de ontwikkeling is, waarin crimineel gedrag

59. Kamerstukken II 2012/13, 33498, 3, p. 6, 21-22.

60. Prop e.a. 2018, p. 3

61. E.M. Mijnarends \& E.R. Rensen, 'De officier van justitie en het adolescentenstrafrecht: twee geloven op één kussen?', Tijdschrift voor Familie- en Jeugdrecht 2017, afl. 3, p. 61.

62. C.S. Barendregt, M.G.C.J. Beerthuizen \& A.M. van der Laan, De toepassing van het jeugdstrafrecht bij jongvolwassenen in de praktijk. Een procesevaluatie van het adolescentenstrafrecht, Den Haag: WODC 2018, p. 7, 9

63. Barendregt, Beerthuizen \& Van der Laan 2018

64. Zie opnieuw VN-Kinderrechtencomité, General Comment No. 24 (2019) on children's rights in the child justice system, CRC/C/GC/24, 2019, par. 2 en VN-Kinderrechtencomité, General Comment No. 14 (2013) on the right of the child to have his or her best interests taken as a primary consideration (art. 3, para. 1), par. 28. het meest voorkomt, maar óók waarin de meeste daders zich weer van de criminaliteit afkeren. ${ }^{65}$

Het lijkt dus verdedigbaar dat jongvolwassenen, indien mogelijk, in meer algemene zin onder het bereik van het jeugdstrafrecht gebracht zouden moeten kunnen worden. Dit idee is in Nederland al eerder verdedigd. ${ }^{66}$ Tegen deze achtergrond moet hier ook worden opgemerkt dat het maar zeer de vraag is of met de huidige individuele benadering, waarin toepassing van artikel 77c Sr een (weinig gebruikte) uitzondering is op de hoofdregel uit artikel 77a, daadwerkelijk recht wordt gedaan aan de relevante wetenschappelijke inzichten. Op basis van deze inzichten kunnen weliswaar betrouwbare conclusies getrokken worden over verschillen in (hersen)ontwikkeling op verschillende leeftijden op groepsniveau, maar (nog) niet over de ontwikkeling van een specifiek individu. ${ }^{67}$ In de huidige situatie heeft het kinderrechtenkader desalniettemin een toegevoegde waarde, omdat het een duidelijkere visie kan bieden op de positie van jongvolwassenen in het strafrecht. Dit is geen overbodige luxe, nu al rond de invoering van de Wet adolescentenstrafrecht werd geconstateerd dat hieraan geen coherente visie ten grondslag lag. ${ }^{68}$ Momenteel wordt de vraag of het in een concreet geval wenselijk is de jongvolwassene te bestraffen binnen het jeugdstrafrecht beantwoord op basis van verschillende en wisselend geinterpreteerde criteria zoals die hierboven werden besproken. Bezien zou kunnen worden of deze criteria nader kunnen worden ingevuld, of aangevuld, op grond van het kinderrechtenperspectief en de bijbehorende redenen voor het toepassen van het jeugdstrafrecht op jongvolwassenen. In die benadering moet de vraag worden gesteld of de gebruikte criteria iets zeggen - en zo ja, wat - over de verwijtbaarheid van de jongvolwassene en/of de mogelijkheden die binnen het jeugdstrafrecht nog bestaan om effectief te intervenieren.

Hoewel de focus van deze bijdrage lag op de positie van jongvolwassenen moet hier ten slotte worden opgemerkt dat de wetswijzigingen uit 2014 werden voorgesteld als initiatieven om de samenleving veiliger te maken, hetgeen negatieve gevolgen had voor de positie van minderjarigen in het strafrecht door diverse verzwaringen van jeugdsancties. ${ }^{69}$ Voortdurende nadruk op kin-

65. Scott, Bonnie \& Steinberg 2016, p. 645-648.

66. Commissie Anneveldt, Sanctierecht voor jeugdigen. Rapport van de commissie herziening strafrecht voor jeugdigen, Den Haag: Sdu 2012. Zie ook over frequentere toepassing van het jeugdstrafrecht op jongvolwassenen als tussenstap naar uiteindelijk eventueel een apart adolescentenstrafrecht: Doreleijers \& Fokkens 2010, p. 41.

67. F.X. Shen, 'Legislating Neuroscience: The Case of Juvenile Justice', Loyola of Los Angeles Law Review 2013, afl. 3, p. 995-996; L. Steinberg, 'Should the Science of Adolescent Brain Development Inform Public Policy?', American Psychologist 2009, p. 746-747.

68. Zie bijv. T. Liefaard, 'Strafrecht voor adolescenten. Een kritische analyse van de plannen van de Staatssecretaris van Veiligheid en Justitie', NJ 2011/1873, p. 2502.

69. Zie het overzicht in Kempen 2014; zie ook Raad voor Strafrechtstoepassing en Jeugdbescherming, Wetsvoorstel adolescentenstrafrecht: een gemiste kans, Den Haag: RSJ 2012. 
derrechten - met daarin aandacht voor het belang van verschillen in ontwikkeling tussen jeugdigen en volwassenen, en voor de balans tussen het belang van de jeugdige dader en dat van de maatschappij - blijft dus ook voor de positie van minderjarigen in het strafrecht onverminderd van belang. Hierbij kan tevens gewezen worden op het reeds herhaaldelijk bekritiseerde, maar nog immer bestaande, artikel $77 \mathrm{~b} \mathrm{Sr}$, op grond waarvan een straf uit het 'volwassen' strafrecht kan worden opgelegd aan een individu dat ten tijde van het begaan van een strafbaar feit 16 of 17 jaar oud was als de rechter daartoe reden ziet in de ernst van het begane feit, de persoonlijkheid van de dader of de omstandigheden waaronder het feit is begaan. ${ }^{70}$ Zeker met betrekking tot de ernst van het feit als een opzichzelfstaande grond om het 'volwassen' strafrecht te kunnen toepassen, blijft het in de rechtspraktijk cruciaal om de grondslagen van het jeugdstrafrecht en de diverse belangen die daarmee gediend kunnen worden (waaronder ook uitdrukkelijk dat van de samenleving, in de vorm van re-integratie van het kind) voor ogen te houden. De korte uiteenzetting in de inleiding van deze bijdrage makkte immers reeds duidelijk dat ook de positie van minderjarigen in het strafrecht ingewikkeld is en voortdurende aandacht behoeft.

\section{Conclusie}

Het onderwerp van kinderrechten op het gebied van het strafrecht is interessant en volop in beweging. Enerzijds is dit onderwerp controversieel en worden zelfs minderjarigen die strafbare feiten plegen niet altijd als 'kind' gezien, met aanspraak op de rechten die bij deze status horen; anderzijds zijn juist op dit vlak internationaal gezien veel ontwikkelingen gaande, bijvoorbeeld in de vorm van de toenemende aandacht voor de positie van jongvolwassenen in het strafrecht.

In deze bijdrage werd onderzocht in hoeverre ook jongvolwassenen aanspraak (zouden moeten) kunnen maken op kinderrechten. Op juridische gronden bestaat daartoe niet direct aanleiding: in beginsel zijn de rechten zoals vastgelegd in het IVRK voorbehouden aan jeugdigen die jonger dan 18 jaar waren ten tijde van het strafbare feit. Wel is vastgesteld dat deze leeftijdsgrens in twijfel kan worden getrokken op basis van wetenschappelijke inzichten in de ontwikkeling van adolescenten en jongvolwassenen, die zijn opgedaan sinds het verdrag werd aangenomen. De redenen om kinderrechten toe te kennen aan minderjarigen, lijken ook van toepassing op jongvolwassenen. Tegen deze achtergrond is het positief dat het comité zich in toenemende mate uitlaat over, en

70. Zie voor deze kritiek bijv. VN-Kinderrechtencomité, Concluding observations on the fourth periodic report of the Netherlands (CRC/C/NDL/CO/4), par. 58-59, maar ook Commissioner for Human Rights, Report by the Commissioner for Human Rights Mr Thomas Hammarberg on his visit to the Netherlands 21-25 September 2008 (CommDH(2009)2), par. 121-122. baseert op, deze inzichten. Aandacht voor deze inzichten is bovendien bij uitstek van belang in de context van het strafrecht. Immers, juist op dit gebied worden kinderrechten als controversieel gezien en wordt het belang van de staat in politieke en maatschappelijke discussies niet zelden tegenover dat van het kind gezet.

Op deze plek kan overigens voor de volledigheid worden opgemerkt dat in andere internationale instrumenten explicieter en duidelijker aandacht wordt besteed aan de positie van jongvolwassenen in het strafrecht. Zo nam het Comité van Ministers van de Raad van Europa een (niet-bindende) aanbeveling aan waarin, op basis van de verlengde transitie naar volwassenheid, werd gesteld dat het mogelijk zou moeten zijn om een jongvolwassene tot 21 jaar te behandelen als jeugdige, als een rechter van oordeel is dat hij of zij nog niet even volwassen en verantwoordelijk is als 'volledig' volwassenen. ${ }^{71}$ De meer behoedzame benadering van het Kinderrechtencomité, dat enkel goedkeuring uitspreekt jegens verdragsstaten die het jeugdstrafrecht toepassen op jongvolwassenen, is overigens wel te begrijpen gegeven hun mandaat als comité dat toezicht houdt op de naleving van de rechten van individuen tot 18 jaar. Toch is het te hopen dat de aandacht voor de positie van jongvolwassenen op internationaal niveau doorzet, en aanzet tot verdere reflectie en discussie, zowel op internationaal als nationaal niveau. Het IVRK wordt gezien als een belangrijk instrument om verandering te bewerkstelligen en kan op dit gebied een mediërende bijdrage leveren voor de invloed van wetenschappelijke inzichten in de ontwikkeling van adolescenten en jongvolwassenen, op de wetgeving die hen raakt.

\section{The Loneliness of the Long-Distance Run- ner}

De zeventienjarige Smith komt uit een gezin aan de rafelranden van de samenleving waar huiselijk geweld en andere criminaliteit aan de orde van de dag zijn. Hij wordt aangehouden op verdenking van diefstal.

“'Listen, my lad," he said, like the dirty bullying jumped-up bastard he was, "I don't mant too much of your lip. Because if me get you domn to the Guildhall you'll get a fem bruises and black eyes for your trouble. "And I knem he masn't kidding either, because I'd heard about all them sort of tricks. I hoped one day though that him and all his pals mould be the ones to get the black eyes and kicks; you never knem. It might come sooner than anybody thinks, like in Hungary. "tell me where the money is, and I'll get you off mith probation." "What 
money?" I asked him, because I'd heard that one before as mell. "You know what money.",72

Smith wordt ondanks zijn ontkenning naar een Borstal, een inrichting voor minderjarige delinquenten, gestuurd. Daar houdt hij zich gedeisd, want de wereld is verdeeld in 'us' en 'them'. Omdat hij aanleg heeft voor hardlopen krijgt hij de vrijheid om te gaan trainen; de directeur wil namelijk dat hij de jaarlijkse crosscountry race tussen verschillende Borstals wint. Tijdens de race loopt hij op kop, maar in het zicht van de finish vertraagt hij bewust om te verliezen ook al beseft hij dat de rest van zijn tijd in de Borstal een hel zal worden door de wraak van de directeur.

\section{Annie Berber en het verdriet van een tedere crimineel}

De jeugdige veroordeelde Tommie doet zijn beklag over de manier waarop het recht met hem omgaat:

'Mijn rapporten zijn mijn grootste vijanden en mijn grootste vrienden. Ze moeten mij in kaart brengen en ze zijn mijn getuigen. Mét die rapporten zal ik eens kunnen aantonen wat ze met me uitgespookt hebben. Als ik tenminste over mijn haat heen ben, mijn moede...

De volgende morgen gingen een heleboel mensen zich met mij bemoeien. Als eerste kmam daar dan-goddank - de dokter bij me kijken. Hij gaf me slaappillen en methadon en ook nog gratis zijn advies over mijn "zaak". "Hoe eerder je de tenlastelegging bekent, hoe eerder je meer vrij bent, ” zei hij. Ik dacht: laat die vent maar lullen. Hij moet alleen mijn pillen uitschrijven, voor de rest is hij onbruikbaar. Hij mas nog niet weg of er kmamen twee rechercheurs, een man en een vroum. Ik vroeg: "Wat gaat er nou met mij gebeuren?" De vroum zei: "Dat moet de Officier van Fustitie beslissen" ... misschien ga je naar het Huis van Bemaring, maar dat moet de Officier van Fustitie beslissen, en hij zal mel erg veel laten afhangen van het feit of jij meemerkt of niet." "Hoe merk ik dan mee?" vroeg ik. "In de eerste plaats door geen onzin te vertellen," zei de man. "En door alles mat je hebt gedaan meteen op te biechten," zei de vroum. Nou, daar hebben ze me de hele dag de tijd voor gegeven, en toen ik bijna afgeknapt mas, kmam er ook nog iemand van de reclassering met mij in de spreekkamer zitten. ...

"Bij Loulou [de kinderrechter] is de psychiater de rechter. Dat is verdomme nog hartstikke link ook. Daar moeten we allemaal verschrikkelijk hard voor

72. A. Sillitoe, The Loneliness of the Long-Distance Runner, Londen: Pan Books (1959) 1974, p. 29-30. gaan schreeumen, want als je op advies van een psychiater behandeld kan worden in plaats van vervolgd, dan zou je dus ook op advies van een psychiater vervolgd kunnen morden in plaats van behandeld! Straks bepaalt de psychiater nog hoeveel maanden je vervolgd moet morden, dan hebben we helemaal geen rechter meer nodig. De macht in handen van de psychiater. Weg met het recht.",73

\section{The Nickel Boys}

Het verhaal speelt in Amerika in 1962, ten tijde van de opkomst van de Civil Rights Movement. De zwarte jongen Elwood Curtis wordt veroordeeld, omdat hij bij aanhouding in de auto zat bij iemand met gestolen spullen in de kofferbak. Op de Nickel Academy, een heropvoedingsinstelling waar Elwood terechtkomt, worden de jongens bij het minste of geringste in een speciale ruimte afgeranseld en gefolterd, soms tot de dood er op volgt. Zo ook Elwood.

'The white boys bruised differently than the black boys and called it the Ice Cream Factory because you came out with bruises of every color. The black boys called it the White House because that was its official name and it fit and didn't need to be embellished. The White House delivered the lam and everybody obeyed. ... Then it mas Elmood's time. The two cells faced each other, separated by a hallway. The beating room had a bloody mattress and a naked pillow that was covered instead by the overlapping stains from all the mouths that had bit into it.... The strap was three feet long with a mooden handle, and they had called it Black Beauty since before Spencer's time, although the one he held in his hand was not the original: She had to be repaired or replaced every so often. The leather slapped across the ceiling before it came domn on your legs, to tell you it mas about to come domn, and the bunk springs made noise with each blow. Elwood held on to the top of the bed and bit into the pillom but he passed out before they mere done, so when people asked him later how many licks he got, he didn't know. ${ }^{74}$ 